\title{
Kecerdasan Adversitas dan Kematangan Karir Terhadap Intensi Berwirausaha
}

\author{
Titien Agustina ${ }^{1}$, Muhammad Darwis Nasution ${ }^{2}$, Sampurnawati $^{3}$ \\ ${ }^{1}$ Dosen Sekolah Tinggi Ilmu Manajemen Indonesia (STIMI) Banjarmasin \\ ${ }^{2,3}$ Wirausahawan
}

\begin{abstract}
This study aims to examine the effect of adversity intelligence and career maturity on the intentions of entrepreneurship in working students. From this research is expected to reinforce the opinion that the students work has a career maturity and also a deeper endurance to bear the business uncertainty with the adversity of intelligence owned so as to strengthen the intentions of student entrepreneurship. The population of the study were 472. Working students of the Slovin formula obtained 83 respondents spread by purposive sampling through certain conditions. The results of research indicate that adversitas intelligence and career maturity, both partially and simultaneously show a positive influence to the intention of entrepreneurship.
\end{abstract}

Key Word: adversity intelligence, career maturity, entrepreneur intention, labor student.

\section{Abstrak}

Penelitian ini bertujuan untuk menguji pengaruh kecerdasan adversitas dan kematangan karir terhadap intensi berwirausaha pada mahasiswa berkerja. Dari penelitian ini diharapkan memperkuat pendapat bahwa pada mahasiswa bekerja memiliki kematangan karir dan juga daya tahan yang lebih dalam menanggung ketidakpastian usaha dengan kecerdasan adversitas yang dimiliki sehingga memperkuat intensi berwirausaha mahasiswa. Populasi penelitian adalah mahasiswa STIMI Banjarmasin yang berjumlah 472. Melalui rumus Slovin didapat sampel 83 responden yang disebar dengan cara purposive sampling melalui syarat tertentu. Hasil penelitian menunjukkan bahwa kecerdasan adversitas maupun kematangan karir, baik secara parsial maupun simultan menunjukkan pengaruh positif dan signifikan terhadap intensi berwirausaha.

Kata kunci: kecerdasan adversitas, kematangan karir, intensi berwirausaha, mahasiswa bekerja

\section{PENDAHULUAN}

Meningkatkan kualifikasi diri (Srimulyani, 2013) menjadi harapan setiap orang, termasuk karyawan yang karena kebutuhan pribadi maupun karena keharusan dari tempat bekerja, maka waktu di luar jam kerja dimanfaatkan lagi untuk menimba ilmu. Menjadi mahasiswa sambil terus bekerja, apakah pada pekerjaan yang sudah menjanjikan kepastian masa depan, baik di Pemerintah sebagai Pegawai Negeri Sipil (PNS), BUMN/D, atau pada perusahaan yang belum tahu perkembangan karir ke depan karena masih merintis, dsb. Pada semua hal tersebut,ada banyak orang mau membagi waktu, tenaga, pikiran, bahkan biaya, untuk menuntut ilmu lagidengan harapan akanada perbaikan hidup di masa depan.

Dari pengalaman bekerja itu juga menimbulkan peluang baru bagi generasi muda untuk menimba pengalaman lagi dan mencari peluang lain dalam mendapatkan uang atau penghasilan tambahan. Misalnya sambil menjadi broker, salesatau tenaga freelance lainnya yang bisa dilakukan sambil meningkatkan kualifikasi pendidikan lewat studi lanjut ke perguruan tinggi. Tren kuliah sambil bekerja sebenarnya sangat membantu proses kematangan karir seseorang bahkan juga berdampak pada penggalian potensi diri dan pengembangan kepribadian sehingga melahirkan kecerdasan adversitas dalam menghadapi persoalan-persoalan dan menemukan solusi setiap persoalan tersebut.

Walaupun peluang menjadi PNS semakin mengecil sejak Pemerintah memberlakukan penundaan sementara (moratorium) di era Pemerintahan Presiden Sosilo Bambang Yudhoyono, dari 1 September 2011 sampai 31 Desember 2012. Moratorium berlanjut pada masa Pemerintahan Presiden Jokowi (2014 hingga 2015). Tahun 2016 hanya mencabut kebijakan moratorium pada jenis pekerjaan dan daerah yang terbatas. Berkurangnya formasi untuk SMA, SMK dan sederajat berimbas juga pada mulai makin terbatasnya keterserapan lulusan Strata 1 (satu). Karena formasi yang tersedia sudah mulai menyempit dan menjurus pada bidang ilmu/keahlian yang lebih terspesifikasi. Oleh karena itu satu-satunya peluang yang sangat besar untuk bekerja adalah dengan memulai usaha atau menjadi wirausaha.

Pada kenyataannya lagi bahwa orientasi yang berkembang sekarang masih dalam lingkup mencari kerja bukan pada menciptakan dan memberi 
pekerjaan. Karena itu ada kesan bahwa bidang kewirausahaan kurang dapat menyentuh intensi berwirausaha kalangan mahasiswa. Hal tersebut di dukung dengan hasil survey BPS (2002) yang menemukan hanya terdapat sekitar 6 persen lulusan perguruan tinggi yang menekuni bidang kewirausahaan, sisanya 94 persen memilih untuk bekerja pada orang lain atau menjadi karyawan. Menurut Marganta (2008) Sekretaris Himpunan Kursus Indonesia (HIPKI), dalam Kedaulatan Rakyat, 28 April 2008, jiwa kewirausahaan generasi muda saat ini masih rendah, sebab kebanyakan lebih tertarik kepada dunia kerja dibandingkan dunia usaha.

Pengertian adversitas adalah kemampuan seseorang dalam menghadapi kesulitan untuk bertahan hidup. Surekha (2001) menyatakan bahwa adversity adalah kemampuan berpikir, mengelola, dan mengarahkan tindakan yang membentuk suatu pola-pola tanggapan kognitif dan perilaku atas stimulus peristiwa-peristiwa dalam kehidupan yang merupakan tantangan atau kesulitan.

Mahasiswa sebagai insan akademis diharapkan mempunyai adversity intelligence atau kecerdasan adversitas yang baik dan tinggi, agar mampu meningkatkan motivasi dalam berwirausaha sehingga dapat menjalankan wirausaha dengan baik dan dapat mengurangi tingkat pengangguran terdidik. Kecerdasan adversitas adalah kemampuan mengubah hambatan menjadi peluang keberhasilan, dapat dipergunakan untuk melepaskan diri dari hambatan, sehingga mahasiswa yang mempunyai kecerdasan adversitas yang baik lebih mampu meningkatkan intensi dalam berwirausaha. Mahasiswa yang mempunyai kecerdasan adversitas rendah menyebabkan mereka tidak mampu mengadapi rintangan yang ada sebab kurang percaya diri lalu merasa ragu-ragu dan takut gagal, sehingga intensi berwirausaha juga rendah.

Dalam Brown (2002) Crites mendefinisikan kematangan kairsebagai tingkat di mana individu telah menguasai tugas perkembangan karirnya, baik komponen pengetahuan maupun sikap, yang sesuai dengan tahap perkembangan karir. Super (Zulkaida et al, 2007) mendefinisikan kematangan karir sebagai keberhasilan seseorang menyelesaikan tugas-tugas perkembangan karir yang khas pada tahap perkembangan tertentu. Sedangkan B. Hasan (2006: 127), menyatakan kematangan karir sebagai sikap dan kompetensi yang berperan untuk pengambilan keputusan karir. Sikap dan kompetensi tersebut mendukung penentuan keputusan karir yang tepat. Dalam Srimulyani (2013) Richard (2007: 171) menyebutkan kematangan karir merupakan refleksi dari proses perkembangan karir individu untuk meningkatkan kapasitas dalam membuat keputusan karir. Crites mendefinisikan kematangan karir individu sebagai kemampuan individu untuk membuat pilihan karir, yang meliputi penentuan keputusan karir, pilihan yang realistik dan konsisten(Brown, 2002).

Dengan demikian, pengertian kematangan karir jauh lebih luas daripada sekedar pemilihan pekerjaan, karena akan melibatkan kemampuan individu baik dalam membuat keputusan karir maupun aktivitas perencanaan karir. Kematangan karir mengarah pada pengenalan karir secara menyeluruh, diawali dengan pengenalan potensi diri, memahami lapangan kerja yang sebenarnya, merencanakan sampai dengan menentukan pilihan karir yang tepat. Bila seorang calon pencari kerja sudah memiliki wawasan tentang pilihan pekerjaan, alternatif karir ke depan, maka memotivasi yang bersangkutan untuk mempersiapkan diri melalui peningkatan kualifikasi diri agar sesuai dengan kebutuhan pasar kerja ke depan.

Hasil penelitian Mayasari (2010) maupun Srimulyani (2013) menunjukkan bahwa terdapat hubungan positif antara kematangan karier dengan minat berwirausaha pada mahasiswa. Artinya semakin tinggi kematangan karir, maka semakin tinggi minat berwirausaha, sebaliknya, semakin rendah kematangan karier, maka semakin rendah pula minat berwirausaha.

Dengan demikian, peserta didik atau mahasiswa yang ada di Perguruan Tinggi adalah insan dewasa yang dianggap sudah memiliki kemampuan atas kesadaran dalam mengembangkan potensi diri untuk menjadi intelektual, ilmuwan, praktisi, dan atau profesional. Apalagi pada mahasiswa bekerja yang sudah mengenal dan memiliki wawasan karir, maka mahasiswa bekerja diharapkan sudah dapat menentukan pilihan karir ke depan sebagai topangan kehidupan yang mapan nantinya setelah menyelesaikan masa studi. Mengingat masih banyaknya sarjana yang menganggur karena tidak memilih kewirausahaan sebagai pilihan pertama pasca di wisuda. Padahal Bygrave menyebut bahwa saat ini adalah masa kewirausahaan (1996:1) sehingga bidang kewirausahaan ini bisa menjadi pilihan pekerjaan yang sangat luas dan terbuka lebar, bahkan juga menjanjikan kehidupan yang mapan sebagaimana jenis pekerjaan/profesi lainnya.

Diperlukan pengertian dan pemahaman yang baik tentang dunia kerja. Salah satunya kewirausahaan, dimana dibutuhkan suatu intensi yang tumbuh dari dalam diri agar berhasil dalam meraih tujuan. Bandura (Wijaya, 2007: 119) menyatakan bahwa: intensi merupakan suatu kebulatan tekad untuk melakukan aktivitas tertentu atau menghasilkan suatu keadaan tertentu di masa depan. Intensi menurutnya lagi adalah bagian vital dari self regulation individu yang dilatarbelakangi oleh motivasi seseorang untuk bertindak.

Menurut teori planned behavior (Azjen \& Fishbein, 1980) intensi merupakan hasil dari bagaimana individu bersikap terhadap suatu objek, nilai-nilai yang ditekankan oleh lingkungan sosial, 
serta keyakinan diri untuk mencapai suatu kesempatan merealisasikan dan perhitungan berhasilnya intensi tersebut. Sangat dekat sekali pengertiannya dengan minat. Ramdhani (2010) menyebutkan intensi kewirausahaan adalah faktor motivasional, yang mempengaruhi individuindividu untuk mengejar hasil-hasil wirausaha (Drucker, 1996). Mengingat berwirausaha adalah semangat, sikap, perilaku, kemampuan seseorang dalam menangani usaha yang mengarah pada upaya, mencari, menciptakan, menerapkan, cara kerja, teknologi, dan produk baru dengan meningkatkan efisiensi dalam rangka memberikan pelayanan yang lebih baik dan memperoleh keuntungan yang lebihbesar.

Oleh karena itu intensi berwirausaha bisa dipengaruhi oleh faktor lingkungan keluarga, karena orang tua akan memberikan corak budaya, suasana rumah, pandangan hidup dan pola sosialisasi yang akan menentukan sikap, perilaku serta proses pendidikan terhadap anak-anaknya. Jika orang tua bekerja sebagai wirausaha maka akan mendukung dan mendorong kemandirian, berprestasi dan bertanggung jawab. Kemudian faktor pendidikan, melalui pendidikan formal akan memberikan pemahaman yang lebih baik tentang proses kewirausahaan, tantangan yang dihadapi para pendiri usaha baru dan masalah-masalah yang harus diatasi agar berhasil. Dalam Rahmawati (2000) Holt mengatakan bahwa melalui pendidikan kewirausahaan akan membentuk mahasiswa untuk mengejar karir kewirausahaan.

Berikutnya faktor nilai personal (faktor kepribadian) yang salah satunya dariintensi berwirausaha yang menyangkut need for achievement, locus of control, dan self-efficacy. Seseorang yang memiliki keinginan kuat (motivasi) untuk berprestasi biasanya mengapresiasikan tanggungjawab personal dan menyukai risiko serta memiliki keinginan kuat untuk memperoleh hasil dari keputusannya.Locus of control mengacu pada persepsi individu tentang kesuksesan dan kegagalan.Semakin tinggi locus of control maka semakin tinggi intensi kewirausahaan seseorang. Self efficacy merupakan keyakinan seseorang terhadap kemampuannya untuk menyelesaikan pekerjaan atau tugas yang dibebankan kepadanya. Persepsi seseorang terhadap self-efficacy memiliki pengaruh yang kuat pada tindakan mereka dan bagaimana pengetahuan dan ketrampilan akan dimanfaatkan (Indarti, 2004).

Kemudian faktor usia juga menurut Roe (Wijaya, 2007) mempengaruhi minat terhadap pekerjaan. Penelitian Strong (Hartini, 2002) yang dilakukan terhadap sejumlah pria berusia 15-25 tahun tentang minat terhadap pekerjaan, menunjukkan bahwa minat berubah secara sedang dan cepat pada usia 15-25 tahun dan sesudahnya sangat sedikit perubahannya. Kemudian factor jenis kelamin juga sangat berpengaruh terhadap minat berwirausaha mengingat adanya perbedaan terhadap pandangan pekerjaan antara pria dan wanita. Sebagaimana penelitian Manson dan Hogg (Wijaya, 2007) mengemukakan bahwa kebanyakan wanita cenderung sambil lalu dalam memilih pekerjaan dibanding dengan pria. Wanita menganggap pekerjaan bukanlah hal yang penting, karena wanita masih dihadapkan pada tuntutan tradisional yang lebih besar menjadi istri dan ibu rumah tangga.

Dalam terbentuknya intensi menurut Ajzen (Sarwoko, 2011: 127) dapat diterangkan dengan Theory of Planned Behavior (TPB) yang mengasumsikan manusia selalu mempunyai tujuan dalam berperilaku. Teori ini menyebutkan bahwa intensi adalah fungsi dari tiga determinan dasar, yaitu: sikap berperilaku (attitude), norma subyektif (subjective norm), dan kontrol perilaku (perceived feasible). Dimana 1) Sikap berperilaku (attitude) merupakan dasar bagi pembentukan intensi. Menurut Saifuddin Azwar (1997: 12), “sikap terhadap suatu perilaku dipengaruhi oleh keyakinan bahwa perilaku tersebut akan membawa hasil yang diinginkan atau tidak diinginkan”. Terdapat dua aspek pokok dari sikap terhadap perilaku, yaitu: keyakinan individu bahwa menampilkan atau tidak menampilkan perilaku tertentu akan menghasilkan akibat-akibat atau hasil-hasil tertentu, dan merupakan aspek pengetahuan individu tentang obyek sikap dapat berupa opini individu yang belum tentu sesuai dengan kenyataan. Semakin positif keyakinan individu akan akibat dari suatu obyek sikap, maka akan semakin positif pula sikap individu terhadap obyek sikap tersebut, demikian pula sebaliknya.

Kemudian 2) Norma subyektif (subjective norm) yaitu keyakinan individu akan norma, orang sekitarnya dan motivasi individu untuk mengikuti norma tersebut. Terdapat dua aspek pokok dalam norma subjektif, yaitu: keyakinan akan harapanharapan, norma referensi dan motivasi kesediaan individu untuk melaksanakan atau tidak melaksanakan pendapat atau pikiran pihak lain yang dianggap penting bahwa individu harus atau tidak harus berperilaku.3) Kontrol perilaku (perceived feasible), yang merupakan dasar bagi pembentukan kontrol perilaku yang dipersepsikan. Kontrol perilaku yang dipersepsikan merupakan persepsi terhadap kekuatan faktor-faktor yang mempermudah atau mempersulit suatu perilaku.

Dengan demikian, ada hubungan antara kematangan karir dengan intensi berwirausaha. Luzzo menyebutkan bahwa kematangan karir merupakan aspek yang penting bagi individu dalam memenuhi kebutuhan akan pengetahuan dan keterampilan untuk membuat keputusan karir yang cerdas dan realistik. Super (Sharf, 1992) berpendapat bahwa keberhasilan dan kesiapan remaja untuk memenuhi tugas-tugas yang terorganisir yang terdapat dalam setiap tahapan 
perkembangan karir disebut sebagai kematangan karir.

Kematangan karir seseorang juga dipengaruhi oleh usia. Kesesuaian usia yang dimaksudkan dalam definisi ini, adalah berdasarkan teori LifeSpan, Life-Space dari Super, yang mengatakan bahwa setiap individu pada jenjang usia tertentu mempunyai peran yang harus dijalankan sesuai dengan tahapan perkembangannya. Sehingga menurut Donald E. Super (Sharf, 1992: 155-159) kematangan karir remaja dapat diukur melalui indikator berikut:

a. Perencanaan karir atau Career Planning adalah kesadaran individu bahwa dirinya harus membuat pilihan pendidikan dan karir, serta mempersiapkan diri untuk membuat pilihan tersebut;

b. Eksplorasi karir atau Career Exploration, dimana individu secara aktif menggunakan berbagai sumber untuk memperoleh informasi mengenai dunia kerja umumnya dan untuk memilih salah satu bidang pekerjaan khususnya;

c. Kompetensi informasional atau World of Work Information adalah kemampuan untuk menggunakan informasi tentang karir yang dimiliki untuk dirinya, serta mulai mengkristalisasikan pilihan pada bidang dan tingkat pekerjaan tertentu), dan

d. Pengambilan keputusan karir atau Career Decision Making, adalah individu mengetahui yang harus dipertimbangkan dalam membuat pilihan pendidikan dan karir, kemudian membuat pilihan pekerjaan yang sesuai dengan minat dan kemampuan.

Sedangkan kecerdasan adversitas adalah kecerdasan untuk menghadapi kesulitan dan kemampuan bertahan dalam berbagai tantangan yang dihadapi (Stoltz, 2000). Kecerdasan adversitas merupakan gambaran kebiasaan individu dalam merespon kesulitan dan ukuran pola bawah sadar yang konsisten yang telah dikembangkan selama bertahun-tahun. Lebih jauh Stoltz (2000) mengatakan bahwa sukses tidaknya individu dalam kehidupan ditentukan oleh kecerdasan adversitas, dimana kecerdasan adversitas dapat memberitahukan: (1)sejauh mana individu mampu bertahan dan mengatasi kesulitan yang dihadapi; (2)individu mana yang mampu mengatasi kesulitan dan yang tidak mampu; (3)individu mana yang akan memenuhi harapan dan potensi serta yang akan gagal; dan (4)individu yang akan menyerah dan yang akan bertahan.

Menurut Stoltz (2000) kecerdasan dalam menghadapi rintangan individu memiliki empat dimensi, yaitu CO2RE (Control, Origin Ownership, Reach, Endurance).

a. Control (C). Dimensi ini berfokus pada kendali yang dirasakan individu terhadap peristiwa yang menimbulkan kesulitan. Nilai tinggi pada dimensi control mengindikasikan bahwa individu mampu mengendalikan peristiwa yang terjadi dalam hidupnya, menemukan cara untuk menghadapi kesulitan, pantang menyerah, dan cepat tanggap dalam mencari penyelesaian.

b. Origin dan ownership (O2)

1) Origin. Dimensi ini berfokus pada penyebab kesulitan. Origin berkaitan dengan rasa bersalah. Nilai tinggi pada dimensi origin mengindikasikan bahwa setiap individu mengalami masa-masa sulit, menganggap kesulitan berasal dari pihak luar dan belajar dari kesalahan yang telah dilakukan.

2) Ownership. Dimensi ini berfokus pada pengakuan terhadap akibat-akibat yang ditimbulkan oleh kesulitan dan mau bertanggung jawab. Nilai tinggi pada dimensi ownership mengindikasikan bahwa individu bersedia bertanggung jawab dan mengakui akibat dari tindakan yang dilakukan.

c. Reach (R). Dimensi ini berfokus pada sejauh mana kesulitan akan mempengaruhi sisi lain dari kehidupan individu. Nilai tinggi pada dimensi reach mengindikasikan bahwa kesulitan yang dihadapi tidak akan mempengaruhi sisi lain kehidupan, merespon peristiwa buruk sebagai hal khusus dan terbatas.

d. Endurance (E). Dimensi ini berfokus pada berapa lama kesulitan dan penyebab kesulitan tersebut akan berlangsung serta kemampuan individu bertahan saat menghadapi kesulitan. Nilai tinggi pada dimensi endurance mengindikasikan bahwa individu optimis, menganggap kesulitan dan penyebab kesulitan sebagai hal yang bersifat sementara, cepat berlalu, dan kecil kemungkinan akan terjadi lagi serta memandang kesuksesan sebagai hal yang berlangsung terus menerus atau bahkan permanen.

Penelitian O'Neil menemukan bahwa mahasiswa dipengaruhi oleh kemampuan, kebutuhan berprestasi, sikap dan pengalaman pribadi yang dimiliki dalam memilih karir. Hal ini menunjukkan bahwa ketika individu memiliki kemampuan di bidang tertentu dan kemudian memperoleh pengalaman maka individu cenderung akan memilih bidang tersebut sebagai pekerjaan yang akan dijalaninya nanti.

Individu yang memiliki kecerdasan dalam menghadapi rintangan akan memiliki kemampuan untuk menangkap peluang usaha (wirausaha) karena memiliki kemampuan menanggung risiko, orientasi pada peluang/ inisiatif, kreativitas, kemandirian dan pengerahan sumber daya, sehingga kecerdasan adversitas memiliki pengaruh terhadap keinginan berwirausaha. Singg (2005) 
menyatakan bahwa mahasiswa yang kuliah sambil bekerja memiliki kematangan karir dan tanggung jawab yang tinggi. Hal ini sejalan dengan pendapat Crites yang menyatakan bahwa untuk dapat memilih dan merencanakan karir yang tepat, dibutuhkan kematangan karir yaitu pengetahuan akan diri, pengetahuan tentang pekerjaan, kemampuan memilih pekerjaan, dan kemampuan merencanakan langkah-langkah menuju karir yang diharapkan. Ini sejalan dengan hasil penelitian Wijaya (2007) yang menemukan bahwa ada hubungan positif yang signifikan antara kecerdasan adversitas dengan intensi kewirausahaan.

Berdasarkan hasil penelitian yang dilakukan oleh Mayasari (2010) menunjukkan bahwa terdapat hubungan positif antara kematangan karir dengan minat berwirausaha pada mahasiswa. Semakin tinggi kematangan karir, maka semakin tinggi minat berwirausaha. Sebaliknya, semakin rendah kematangan karir, maka semakin rendah pula minat berwirausaha. Hal ini sejalan pula dengan hasil penelitian Pratama (2010) yang juga menunjukkan bahwa terdapat hubungan positif antara kematangan karir dengan intensi berwirausaha pada mahasiswa. Semakin tinggi kematangan karir, maka semakin tinggi intensi berwirausaha. Sebaliknya, semakin rendah kematangan karir, maka semakin rendah intensi berwirausaha.

\section{METODE PENELITIAN}

Penelitian ini termasuk jenis penelitian eksplanatori (explanatory research) yaitu suatu penelitian untuk mencari dan menjelaskan hubungan kausal antar variabel. Objek penelitian ini meliputi variable-variabel yang diteliti adalah kecerdasan adversitas (X1), kematangan karir (X2), dan intensi berwirausaha (Y)mahasiswa STIMI Banjarmasin. Penelitian ini menganalisis kecerdasan adversitas dan kematangan karir terhadap intensiberwirausaha mahasiswa STIMI Banjarmasin.

Populasi penelitian ini yaitu mahasiswa STIMI Banjarmasin Prodi Manajemen Strata 1 angkatan 2013, 2014, dan 2015 yang menurut data Forlap Ristek Dikti, berjumlah 472 orang, dengan menggunakan rumus Slovin (Sanusi, 2014: 101) didapat jumlah sampel sebanyak 83 orang. Teknik sampling yang digunakan adalah purposive sampling. Teknik purposive samplingmaksudnya adalah cara pengambilan sampel yang didasarkan pada pertimbangan-pertimbangan tertentu (Sanusi, 2014:95), yaitu:

a. Mahasiswa yang berdasarkan nomor induknya tercatat sebagai salah satu

dari 3 angkatan ini, yaitu 2013- 2015

b. Status aktif kuliah di PDPT dan atau feeder

c. Bekerja sambil kuliah d. Telah memprogram dan lulus dalam mata kuliah Pengantar Bisnis dan atau Kewirausahaan

e. Sudah bekerja, minimal 1 (satu) tahun atau lebih.

Adapun teknik pengumpulan data yang digunakan yaitu angket/kuesioner dan dokumentasi. Sedangkan sumber data yang digunakan dalam penelitian ini diambil dari dua kategori sumber, yaitu sumber primer dan sumber sekunder. Data primer berupa data yang diperoleh langsung dari setiap responden yang terpilih sebagai sampel dengan kriteria tersebut diatas secara proporsional. Sehingga mahasiswa angkatan tahun 2013 diambil sebanyak 28 orang, angkatan tahun 2014 diambil berjumlah 23 orang dan angkatan tahun 2015 diambil berjumlah 32 orang.

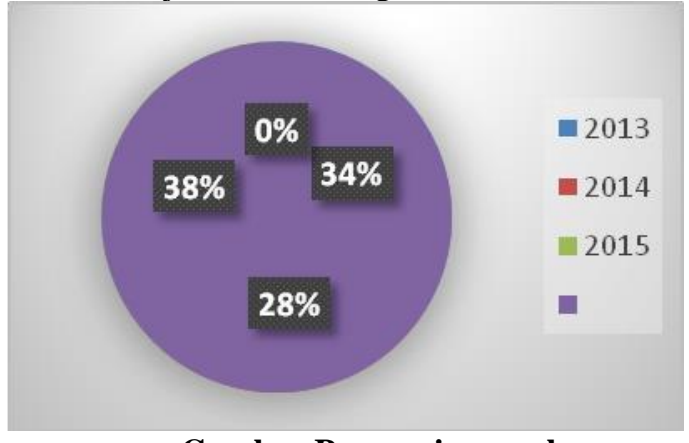

Gambar Proporsi sampel

Data sekunder berupa data yang diperoleh dari dokumen-dokumen terkait dengan variabel yang diamati guna mendukung pernyataan dan teori yang telah dibangun, sehingga dapat menunjang penelitian.

Model kerangka penelitian adalah sebagai berikut:

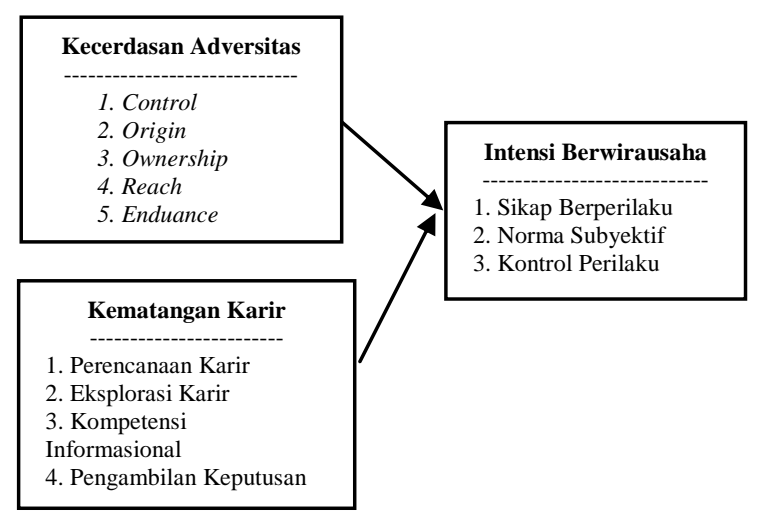

\section{Gambar 1 Model kerangka penelitian}

Keterangan

Keterangan :

Hubungan Regresi

Hubungan Korelasi 


\section{HASIL PENELITIAN DAN PEMBAHASAN}

Berdasarkan hasil tabulasi dari identitas responden, dapat dikemukakan deskripsi profil responden dalam penelitian ini dimanaperempuan berjumlah 40 orang $(48,19 \%)$ dan laki-laki berjumlah 43 orang $(51,81 \%)$.

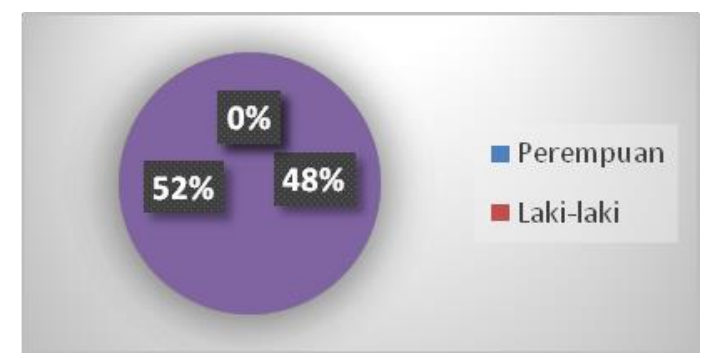

\section{Gambar 2 Deskripsi Responden berdasarkan Jenis Kelamin}

Berdasarkan usia, responden paling dominan adalah berusia 21 - 25 tahun berjumlah 40 orang $(48,19 \%)$, berusia 26 - 30 tahun berjumlah 19 orang $(22,89 \%)$. Responden berusia $\leq 20$ tahun berjumlah 9 orang $(10,84 \%)$. Responden Berusia lebih dari 40 tahun berjumlah 6 orang $(7,23 \%)$ dan responden berusia 36 - 40 tahun berjumlah 2 orang $(2,41 \%)$.

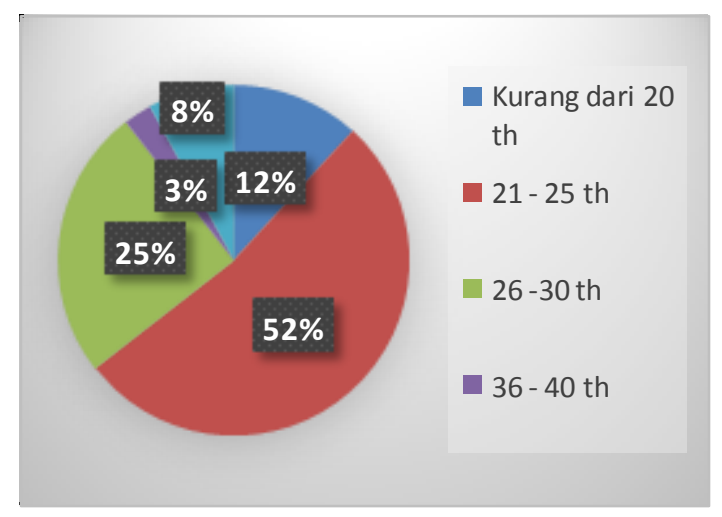

\section{Gambar 3 Deskripsi Responden berdasarkan Usia}

Berdasarkan lama bekerja maka responden yang sudah bekerja antara $1-5$ tahun adalah 60 orang $(72,29 \%)$. Lama bekerja $6-10$ tahun berjumlah 13 orang $(15,66 \%)$, lamabekerja $11-15$ tahun berjumlah 4 orang $(4,82 \%)$ dan tidak ada responden $(0,0 \%)$ yang lama bekerjanya antara $16-$ 20 tahun, sedangkan yang lama bekerja lebih dari 20 tahun berjumlah 6 orang $(7,23 \%)$.

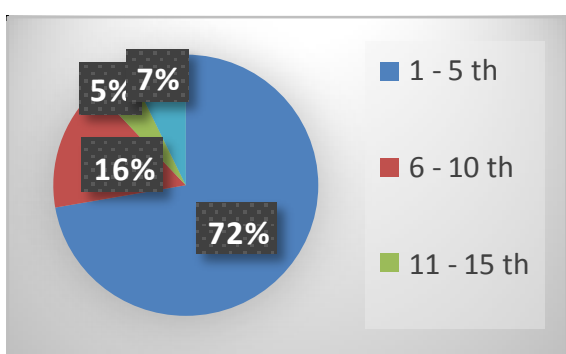

Gambar 4 Deskripsi Responden berdasarkan Lama Bekerja
Sebelum dilakukan pengumpulan data penelitian ini, terlebih dahulu dilakukan uji instrumen penelitian yang berupa angket atau kuesioner. Uji validitas dan reliabilitas dilakukan terhadap variabel kecerdasan adversitas, kematangan karir, dan intensi kewirausahaan. Semua pengujian menunjukkan hasil yang valid dengan masing-masing nilai $\mathrm{r}$ hitung $>\mathrm{r}$ tabel, yaitu> 0,44. Dengan demikian semua item kuesioner dalam penelitian ini dinyatakan valid.

Untuk uji reliabilitas instrumen penelitian melalui kriteria pengujian reliabilitas jika nilai Cronchbach's Alpha $>0,6$, maka kuesioner dinyatakan reliabel. Dari hasil uji reliabilitas nilai Cronchbach's Alpha kuesioner variabel kecerdasan adversitas adalah 0,951. Nilai Cronchbach's Alpha kuesioner variabel kematangan karir berjumlah 0,954, dan nilai Cronchbach's Alpha kuesioner variabel intensi kewirausahaan mencapai 0,953. Kemudian Nilai Cronchbach's Alpha ketiga variabel tersebut adalah $>0,6$. Jadi semua kuesioner penelitian ini dinyatakan reliabel.

Berdasarkan hasil uji kuesioner selanjutnya dilakukan analisis deskriptif terhadap variabel kecerdasan adversitas (X1), kematangan karir (X2), dan intensi kewirausahaan (Y) dengan menghitung nilai rata-rata. Kriteria ditentukan dengan menghitung range yaitu 5-1 $=4$, kemudian 4:5=0,8. Jadi jarak interval 0,8 digunakan untuk membuat kelas interval.

Berdasarkan hasil deskripsi maka nilai ratarata kecerdasan adversitas 4,317 (sangat tinggi). Aspek kendali peristiwa (locus of control) memiliki nilai tertinggi dalam kecerdasan adversitas dibandingkan yang lain yaitu mencapai rata-rata 4.54 (sangat tinggi). Item percaya selalu ada cara untuk keluar dari masalah mencapai rata-rata tertinggi 4,65 (sangat tinggi). Aspek terendah merespon masa sulit yaitu mencapai rata-rata 3,87 (tinggi). Kemudian untuk hasil deskripsi kematangan karir dalam kewirausahaan mahasiswa menunjukkan bahwa nilai rata-rata mencapai 4.20 (sangat tinggi). Aspek perencanaan karir dalam variabel kematangan karir ini mencapai rata-rata tertinggi yaitu 4,47 (sangat tinggi). Aspek terendah adalah kompetensi informasi mencapai rata-rata 4.07 (tinggi). Item tertinggi yaitu kesadaran merencanakan masa depan sekarang dengan ratarata 4,59 (sangat tinggi). Item terendah bertanya kepada pihak kompeten mengenai bidang pekerjaan yang diminati dengan rata-rata 3,83 (tinggi).

Dari deskripsi intensi kewirausahaan mahasiswa didapat nilai rata-rata variabel mencapai rata-rata 3,901 (tinggi). Aspek tertinggi dalam intensi kewirausahaan ini adalah kontrol perilaku yaitu 4,053 (tinggi). Aspek terendah adalah norma subjektif, 3,7 (tinggi). Item yang tertinggi adalah jika mengalami kegagalan yakin dapat bangkit dengan nilai rata-rata 4,23 (tinggi sekali). Item 
terendah adalah teman dekat menyarankan berwirausaha dengan rata-rata 3,63 (cukup).

Melalui uji asumsi dengan autokorelasi dengan membandingkan nilai Durbin Watson hitung dengan Durbin Watson pada tabel, maka pada data penelitian ini tidakmengalami gejala autokorelasi. Juga tidak menunjukkan terjadinya multikolineritas serta gejala heterokedastisitas.

Koefisien determinan digunakan untuk mengetahui berapa besar variabel kecerdasan adversitas (X1) dan variabel kematangan karir (X2) terhadap intensi kewirausahaan (Y). Hasil analisis regresi berganda menunjukkan nilai $\mathrm{R}$ (Koefisien determinan) sebesar 0,72 dan nilai $R^{2}$ (Koefisien determinan yang dikuadratkan atau $\mathrm{R}$ square) sebesar 0,529. Ini berarti bahwa variabel intensi kewirausahaan dipengaruhi kombinasi variabel kecerdasan adversitas dan kematangan karir sebesar $52,9 \%$. Sisanya sebesar $47,1 \%$ dipengaruhi faktor lain di luar model penelitian ini sebagaimana tabel 1 berikut:

Tabel 1

Koefisien Determinan

\begin{tabular}{lrrrr}
\hline Model & $\mathrm{R}$ & $R$ Square & $\begin{array}{r}\text { Adjusted } \\
R \text { Square }\end{array}$ & $\begin{array}{c}\text { Std. Error } \\
\text { of the } \\
\text { Estimate }\end{array}$ \\
\hline & $0,728^{\mathrm{a}}$ & 0,529 & 0,518 & 7,48465 \\
\hline
\end{tabular}

Pada tabel2 berikut untuk uji $\mathrm{F}$ atau uji pengaruh simultan menunjukkan Nilai $F$ hitung dan nilai signifikansi pada tabel di atas dapat digunakan untuk menguji pengaruh simultan variabel kecerdasan adversitas (X1) dan variabel kematangan karir (X2) terhadap intensi kewirausahaan (Y). Selain itu nilai $F$ juga digunakan untuk menentukan kelayakan model penelitian ini. Kriteria yang digunakan untuk menguji pengaruh simultan dan kelayakan model itu adalah dengan membandingkan nilai $\mathrm{F}$ hitung dengan $\mathrm{F}$ tabel. Jika nilai $\mathrm{F}$ hitung $>\mathrm{F}$ tabel dan Nilai signifikansi $<0,05$, maka terdapat pengaruh signifikan variabel kecerdasan adversitas (X1) dan variabel kematangan karir (X2) terhadap intensi kewirausahaan (Y). Model penelitian ini sudah dianggap layak.

Tabel 2

Uji Pengaruh Simultan

\begin{tabular}{lccccc}
\hline \multirow{2}{*}{ Model } & $\begin{array}{c}\text { Sum of } \\
\text { Squares }\end{array}$ & Df & $\begin{array}{c}\text { Mean } \\
\text { Square }\end{array}$ & F & Sig. \\
\hline $1 \quad$ Regression & 5040,357 & 2 & 2520,178 & 44,987 & $0,000^{\mathrm{a}}$ \\
& & & & & \\
Residual & 4481,595 & 80 & 56,020 & & \\
\hline Total & 9521,952 & 82 & & \\
\hline
\end{tabular}

Tabel 2 tersebut menujukkan nilai $\mathrm{F}$ hitung 44,987 dan signifikansi 0,000. Nilai $F$ tabel diketahui dengan menggunakan $\mathrm{d} 21 \mathrm{dan}$ df 2 . Nilai F tabel pada df 1 sebesar 2 dan df 2 sebesr 80 dengan taraf signifikan $5 \%$ adalah 3,15 . Nilai $F$ hitung sebesar 44,987 > F tabel sebesar 3,15. Nilai signifikansi $0,000<0,05$. Dengan demikian variabel kecerdasan adversitas (X1) dan variabel kematangan karir (X2) berpengaruh signifikan secara simultan terhadap intensi kewirausahaan (Y). Berdasarkan hal tersebut maka model penelitian ini dianggap layak.Sedangkan untuk uji parsial terlihat pada tabel 3 berikut.

Tabel 3

Uji Parsial

\begin{tabular}{|c|c|c|c|c|c|}
\hline \multirow{3}{*}{ Model } & \multicolumn{2}{|c|}{$\begin{array}{c}\text { Unstandardized } \\
\text { Coefficients }\end{array}$} & $\begin{array}{l}\text { Standardized } \\
\text { Coefficients }\end{array}$ & \multirow{3}{*}{$\mathrm{t}$} & \multirow{3}{*}{ Sig. } \\
\hline & & Std. & & & \\
\hline & B & Error & Beta & & \\
\hline \multirow[t]{2}{*}{1 (Constant) } & - & & & & \\
\hline & 11,921 & 9,538 & & $-1,250$ & 0,215 \\
\hline $\mathrm{X} 1$ & 0,615 & 0,166 & 0,373 & 3,709 & 0,000 \\
\hline $\mathrm{X} 2$ & 0,995 & 0,233 & 0,429 & 4,268 & 0,000 \\
\hline
\end{tabular}

Pengaruh variabel kecerdasan adversitas (X1) dan variabel kematangan karir (X2) terhadap intensi kewirausahaan (Y) secara parsial diketahui dengan melihat nilai $t$ hitung dan signifikansi pada Tabel 3di atas. Jika signifikansi < 0,05, maka dapat dikatakan terdapat pengaruh signifikan antara variabel kecerdasan adversitas (X1) dan variabel kematangan karir (X2) terhadap intensi kewirausahaan (Y) secara parsial.

Nilai t sebesr 3,709 dengan signifikan 0,000 berarti terdapat pengaruh signifikan variabel kecerdasan adversitas (X1) terhadap intensi kewirausahaan (Y). Nilai t sebesar 4,268 dengan signifikansi 0,000 bermakna bahwa variabel kematangan karir (X2) berpengaruh signifikan terhadap intensi kewirausahaan (Y).

Selanjutnya nilai B tabel dapat membantu menentukan garis persamaan regresi. Persamaan garis regresi dapat memberikan penjelasan kenaikan masing-masing variabel independen mempengaruhi kenaikan variabel dependen. Nilai B variabel kompetensi (X1) sebesar 0, 615 dan nilai B variabel pelatihan (X2) sebesar 0,995. Nilai konstanta $-11,921$. Garis persamaan regresi dibuat sebagai berikut:

$\mathrm{Y}=-11,921+0,615 \mathrm{X} 1+0,995 \mathrm{X} 2+\mathrm{e}$

Maksud dari persamaan garis regresi di atas sebagai berikut. 
1) Konstanta sebesar -11,921 menunjukkan intensi kewirausahaan $(\mathrm{Y})=6,608$, apabila variabel bebas dianggap konstan atau tidak berubah. Nilai kinerja $-11,921$ jika tidak terjadi peningkatan kecerdasan adversitas (X1) dan kematangan karir (X2).

2) Nilai B kecerdasan adversitas 0,615 dapat dijelaskan bahwa apabila terjadi kenaikan skor kecerdasan adversitas sebesar satu satuan maka intensi kewirausahaan akan meningkat sebesar0,615, jika variabel bebas lain dianggap konstan.

3) Nilai B kematangan karir 0,995 dapat dijelaskan bahwa apabila terjadi kenaikan skor kematangan karir sebesar satu satuan maka intensi kewirausahaan akan meningkat sebesar 0,995, jika variabel bebas lain dianggap konstan.

Temuan penelitian ini menunjukkan bahwa terdapat pengaruhkecerdasan adversitas dan kematangan karir terhadap intensi berwirausaha mahasiswa STIMI Banjarmasin, baik secara parsial maupun secara simultan. Temuan ini mendukung hasil penelitian yang dilakukan oleh Mayasari (2010); Pratama (2010); Aji et al. (2011), Srimulyani (2013); Amalia dan Muhari (2013); Wulandari, et al. (2013); Handaru, et al. (2015); Ayis Crusman Fradani (2016); Yunda Sanggar Puri (2016).

Berikutnya pada kecerdasan adversitas mahasiswa bekerja yang berpengaruh terhadap intensi berwirausaha mahasiswa STIMI Banjarmasin, menunjukkan bahwa aspek kendali peristiwa (locus of control) dalam kecerdasan adversitas terbukti mempengaruhi intensi berwirausaha mahasiswa. Artinya bahwa mahasiswa STIMI Banjarmasin memiliki kendali diri yang baik di dalam menentukan pilihan karir kedepan melalui intensi kewirausahaan. Berarti mahasiswa sadar bahwa ada pilihan karir yang lain yang juga cukup menjanjikan, yaitu dengan berwirausaha dan pilihan ini bisa menciptakan lapangan kerja juga buat orang -orang disekitar. Ini sejalan dengan hasil penelitian Cahyono (2010), Aji et al. (2011).

Dari pernyataan rasa percaya diri bahwa selalu ada cara untuk keluar dari setiap masalah memberikan kontribusi maksimal terhadap intensi berwirausaha. Artinya mahasiswa memiliki rasa percaya diri yang baik untuk berwirausaha, terbukti dengan kepercayaan dirinya bahwa selalu ada cara untuk keluar dari setiap persoalan. Berarti mahasiswa menyadari bahwa pada dunia kewirausahaan masalah merupakan tanggung jawab pribadi dan risiko yang harus dihadapi, sekaligus dicarikan solusinya melalui kreativitas pribadi.

Aspek terendah merespon masa sulit menjadi bahan masukan untuk meningkatkan kecerdasan adversitas yang diharapkan memberikan pengaruh pada intensi berwirausaha lebih besar. Ini menunjukkan bahwa mahasiswa percaya bahwa masa sulit dalam setiap hal selalu ada dan merupakan hal yang sangat manusiawi. Oleh karena itu masa sulit memang tidak bisa dihindari, tetapi harus dikelola dengan baik. Melalui kecerdasan adversitas maka masa sulit bisa membuka peluang bahkan kesempatan untuk lebih menggali potensi diri melalui kreativitas, inisiatif, dan inovasiinovasi yang dilakukan selama mencari dan menemukan solusi. Sehingga daya tahan selama menghadapi persoalan menjadi sumber kekuatan sekaligus peluang untuk sukses berikutnya. Karena kesuksesan pada setiap orang itu unik sifatnya. Tidak ada yang sama persis jalannya, caranya, maupun tahapannya.

Secara keseluruhan hasil penelitian ini mendukung temuan penelitian Srimulyani (2013) yang dilakukan di Universitas Widya Mandala Madiaun, Fradani (2016) yang melakukan penelitian pada Siswa SMK Negeri 2 Bojonegoro. Bahwa pada siswa maupun mahasiswa sebagai objek penelitian intensi berwirausaha apabila memiliki kecerdasan adversitas atau kecerdasan menghadapi rintangan akan lebih siap menjalani profesi sebagai seorang wirausaha karena mereka memiliki kemampuan untuk membuat hambatan menjadi peluang. Sebagaimana juga teori dari Paul Stolz (2007) juga mendukung hasil penelitian ini. Juga hasil penelitian dari Wijaya (2007), Wulandari et.al (2013), Handaru et. al (2015), Puri (2016).

Temuan penelitian ini menunjukkan bahwa mahasiswa bekerja telah memiliki kendali yang baik atas peristiwa di dalam menangkap peluang dan kesempatan yang ada di sekitar sehingga telah memiliki intensi kewirausahaan yang cukup baik. Sebagaimana penelitian Aji et. al (2011). Melalui rasa kepercayaan yang ada dalam diri bahwa setiap persoalan atau masalah selalu ada cara untuk mengatasi kesulitan sehingga bisa menemukan jalan keluar yang terbaik, maka keyakinan ini bisa membantu seseorang menjadi cerdas dan kreatif dalam membuat hambatan menjadi peluang dan akhirnya menemukan solusi dari persoalan itu. Dengan demikian jelas bahwa pada mahasiswa bekerja telah memiliki kecerdasan adversitas yang cukup baik sehingga bisa menangkap peluang dalam membentuk kematangan karir ke depan.

Pada variabel kematangan karir ditemukan bahwa ada pengaruh signifikan terhadap intensi kewirausahaan mahasiswa STIMI Banjarmasin, ini menunjukkan bahwa aspek perencanaan karir dalam variabel kematangan karir ini menonjol dalam memberikan pengaruh terbentuknya kematangan karir.

Kesadaran merencanakan masa depan dari awal atau sedini mungkin memberikan kontribusi maksimal terhadap intensi kewirausahaan. Aspek kompetensi informasi dan rajin bertanya kepada pihak berkompeten mengenai bidang pekerjaan yang diminati belum maksimal sehingga dapat 
dijadikan masukan untuk ditingkatkan dengan harapan dapat memberikan kontribusi pada variabel kematangan karir yang mempengaruhi intensi kewirausahaan.

Temuan penelitian ini juga menunjukkan bahwa mahasiswa bekerja lebih memiliki kesadaran akan masa depan melalui perencanaan karir terhadap apa yang diminati untuk masa depan atau kematangan karir. Ini sejalan dengan penelitian Aji et al., (2011). Namun terdapat kelemahan dalam hal kurang bisa memanfaatkan informasi yang berlimpah sekarang ini sehingga menjadikan ini sebagai cara atau sarana untuk mendukung perencanaan karir yang diinginkan ke depan. Padahal dalam era globalisasi dan berlimpahnya informasi dengan dukungan teknologi informasi (TI) yang sudah luar biasa, bisa menjadi sangat memudahkan serta sangat mendukung dalam mendapatkan informasi yang tepat bahkan bisa membimbing penemuan karir yang tepat ke depan. Namun sayang mahasiswa masih belum efektif dalam memanfaatkan informasi yang ada disekitar guna mendukung pengembangan wawasan karir masa depan. Salah satu karena belum memanfaatkan kemudahan sarana komunikasi dari teknologi digital yang ada disekitar guna mendapatkan informasi karir yang tepat. Media komunikasi dan informasi yang dimiliki masih lebih banyak digunakan untuk media sosial lainnya saja yang sebenarnya bila kreatif sangat bisa untuk mendukung penemuan karir yang diinginkan ke depan, bahkan masuk dalam pasar kerja global. Kekurangan ini bisa menjadi sarana buat pelitian lebih lanjut tentang hal itu. Hasil penelitian ini mendukung penelitian terdahulu dari Mayasari (2010), Srimulyani (2013) dan Fradani (2016).

Sejalan dengan pendapat Mc Clelland (1989) bahwa suatu negara dianggap maju bila telah memiliki minimal dua persen dari seluruh penduduknya adalah pengusaha sukses. Salah satu cara untuk mencetak wirausaha sukses adalah melalui mahasiswa yang kelak diharapkan mampu menangkap peluang usaha dan melahirkan kreativitas serta inovasi-inovasi baru dalam masyarakat. Apalagi bila ditunjang dengan kecerdasan adversitas dan kematangan karir yang diperoleh dan dibentuk selama kuliah dan masa transisi dalam membangun karir ini. Sehingga tren kuliah sambil bekerja sebenarnya sangat membantu proses kematangan karir seseorang bahkan juga berdampak pada penggalian potensi diri dan pengembangan kepribadian sehingga melahirkan kecerdasan adversitas dalam menghadapi persoalan-persoalan dan menemukan solusi setiap persoalan tersebut, lebih kreatif, penuh inisiatif, dan mampu berinovasi.

\section{PENUTUP}

Telah tumbuh kesadaran akan pentingnya pengembangan diri dan peningkatan kualifikasi diri pada generasi muda sekarang, sehingga mampu mendorong banyak orang muda mau saja menjalani sebagai pekerja sekaligus juga studi lanjut (kuliah) dengan menjadi mahasiswa. Melalui penelitian ini dapat disimpulkan:

1. Kecerdasan adversitas berpengaruh positif dan signifikan terhadap intensi berwirausaha mahasiswa bekerjapada STIMI Banjarmasin. Hal ini berarti bahwa semakin tinggi kecerdasan adversitas yang ada pada diri seorang mahasiswa, maka intensi berwirausaha yang dimiliki juga akan semakin baik.

2. Kematangan karir berpengaruh positif dan signifikan terhadap intensi berwirausaha mahasiswa bekerjapada STIMI Banjarmasin. Hal ini berarti bahwa semakin baik kematangan karir yang dimiliki seorang mahasiswa, maka akan makin memantapkan kesadaran akan pilihan berwirausaha. Dengan demikian intensi berwirausaha menjadi makin tinggi seiring makin matangnya pengalaman karir mahasiswa.

3. Kecerdasan adversitas dan kematangan karir sama-sama berpengaruh positif dan signifikan terhadap intensi berwirausaha mahasiswa bekerja pada STIMI Banjarmasin. Hal ini berarti bahwa makin tingginya kecerdasan adversitas dan kematangan karir mahasiswa bekerja tersebut, maka akan makin baik intensi berwirausaha seroang mahasiswa bekerja, bahkan makin mendorong dan memantapkan pilihan karir ke depan.

\section{Rekomendasi}

Hasil penelitian ini merekomendasikan agar mahasiswa mampu memanfaatkan teknologi informasi secara maksimal untuk mendapatkan wawasan kerja yang sesuai dengan kebutuhan jaman sehingga memiliki kematangan karir yang baik. Selain itu juga melalui pemanfaatan teknologi informasi yang canggih di tangan bisa makin memantapkan intensi berwirausaha di dalam diri, agar terbiasa dengan pola pikir dan pola sikap yang penuh inisiatif, kreativitas, dan inovasi sehingga mampu menangkap peluang-peluang baru yang melahirkan kecerdasan adversitas dan kematangan karir yang lebih baik lagi.

Bagi penelitian selanjutnya direkomendasikan untuk melakukan penelitian yang terkait dengan pemanfaatan kemajuan teknologi digital oleh mahasiswa bekerja dalam merintis star up yang berpeluang menjadi usaha menengah dan besarserta mampu menemukan model bisnis baru yang seiring perkembangan jaman. 
Rekomendasi lainnya adalah guna menyikapi perubahan pasar kerja dan tuntutan jaman, maka perlu mempersiapkan kaum muda yang kreatif sehingga mampu menciptakan lapangan kerja baru. Salah satunya dengan menjadikan kewirausahaan sebagai mata kuliah pada setiap bidang/program studi apapun, sehingga tidak ada lagi istilah sarjana yang menganggur.

\section{DAFTAR PUSTAKA}

Aji, Rahmanto, Sri Hartati, dan Diana Rusmawati. 2011. "Hubungan antara Locus of Control Internal dengan Kematangan Karir pada Siswa Kelas XII SMKN 4 Purworejo." Fakultas Psikologi Universitas Diponegoro.

http://eprints.undip.ac.id/24802/1/LOC_internal_da n_Kematangan_Karir.pdf. Didownload tanggal 2 Desember 2015.

Azjen, I\& Fishbein, W. 1980. Understanding Attitudes and Predicing Social Behavior. Englewood Cliffs, NJ: Prentice-Hall.

Azwar, Syaifuddin. 1997. Sikap Manusia: Teori dan Pengukurannya. Yogyakarta: Pustaka Pelajar Offset.

Badan Pusat Statistik. 2002. Statistik Indonesia. Jakarta: BPS.

Bygrave, D. William, 1996. The Fortable MBA Entrepreneurship. Penerbit Andi Tandur, Jakarta.

Brown, D. (Eds.).2002. Career Choice and Development (4 Ed). United States of America: Jossey-Bass.

Cahyono, Andi. 2010. "Faktor-faktor yang Mempengaruhi Intensi Kewirausahaan Mahasiswa Program Studi Bisnis Universitas Kristen Petra Surabaya tahun 2006-2009.

http://digilib.petra.ac.id/2010/jiunkpe-nss1-2010-31406037-16679-kewirausahaanabstract_toc.pdf. Didownload 15 Desember 2015.

Drucker, Peter., 1996. Konsep Kewirausahaan Era Globalisasi, Terjemahan, Jakarta: Erlangga.

Fradani, Ayis Crusman, 2016. Pengaruh Dukungan Keluarga, Kecerdasan Adversitas, dan Efikasi Diri pada Intensi Berwirausaha Siswa SMK Negeri 2 Bojonegoro. Jurnal Edutama, Vol. 3, No. 1 Januari 2016.

Handaru, Agung Wahyu; Parimita, Widya; dan Mufdhalifah, Inka Winarni, 2015. Membangun Intensi Berwirausaha melalui Adversity Quotient, Self Efficacy, dan Need for Achievement. Jurnal Manajemen dan Kewirausahaan, Vol. 17, No. 2, September 2015: 145-166.
Hartini. 2002. Intensi Wirausaha Pada Siswa SMK. Universitas Wangsa Manggala Yogyakarta.

Hasan, B. (2006). Career Maturity of Indians Adolescents as A Function of Self Concept, Vocational Aspiration and Gender. Journal of the Indian Academy of Applied Psychology (No. 2 Vol. 32 February 2006). p. 127-134.

Indarti, N., 2004. "Factors affecting entrepreneurial intentions among Indonesian students." International Journal of Entrepreneurial Behaviour and Research, Vol 3 (2): 93110

Marganta. 2008. Kedaulatan Rakyat, 28 April 2008.

Mayasari, I. 2010. "Hubungan antara Kematangan Karir dengan Minat Berwirausaha pada Mahasiswa." Fakultas Psikologi Universitas Muhammadiyah Surakarta. [On- Line]. Available FTP: Didownload tanggal 24 Januari 2016.

Pratama, Nanang S. 2010. "Hubungan antara Kematangan Vokasional dengan Intensi Berwirausaha pada Mahasiswa." Fakultas Psikologi, Universitas Muhammadiyah Surakarta: Didownload tanggal 24 Januari 2016.

Puri, Yunda Sanggar, 2016. Hubungan antara Adversitas Quotient dengan Minat Berwirausaha Siswa kelas XII Pemasaran di $\quad$ SMKN 11 Surabaya. ejurnal.unesa.ac.id/article/3501/54/article .$p d f$. Di download tanggal 17 Agustus 2016.

Rahmawati, 2000. Pendidikan Wirausaha Dalam Globalisasi. Yogyakarta: Liberty.

Ramdhani, Pratama Rus. 2010. Pengertian Intensi Kewirausahaan http://matakuliahekonomi.wordpress.com. Didownload tanggal 23 Desember 2015.

Sanusi, Anwar. 2014. Metodologi Penelitian. Jakarta: Salemba Empat.

Sarwoko, Endi. 2011. "Kajian Empiris Entrepreneur Intention Mahasiswa." Jurnal Ekonomi Bisnis (Vol. 16, No. 2). Hlm. 129-130.

Sharf, Richard S. (1992). Applying Career Development Theory to Counseling. California: Books/Cole Publishing Company.

Srimulyani, Veronica Agustini, 2013. Analisis Pengaruh Kecerdasan Adversitas, Internal Locus of Control, dan Kematangan Karier terhadap Intensi Berwirausaha Pada Mahasiswa Bekerja (Studi Empiris pada Mahasiswa Kelas Karyawan Unika Widya Mandala Madiun), Jurnal Widya Warta No. 01 Tahun XXXV II/ Januari 2013 ISSN 0854-1981, pp. $96-110$. 
Stoltz. Paul. 2000. Adversity Intellengence. Yogyakarta: Liberty.

Surekha. 2001. Adversity Intellengence. Jakarta: Pustaka Umum

Wijaya, Tony.2007. "Hubungan Adversity Intelligence dengan Intensi Berwirausaha (Studi Empiris pada Siswa SMKN 7 Yogyakarta)." Jurnal Manajemen dan Kewirausahaan, Vol 9, No. 2. hal: 117127.

Wulandari, Siti Zulaikha; Asteria Pudyantini, dan Yayat Giyatno, 2013. Analysis The Influence of Adversity Quotient, Networking and Capital Through The
Entrepreneurial Intentions of Unsoed's Student. feb.unsoed.ac.id.index.php/sca1/article. Di download tanggal 17 Agustus 2016.

Zulkaida, A, dkk. 2007. "Pengaruh Locus of Control dan Efikasi Diri Terhadap Kematangan Karir Siswa Sekolah Menengah Atas (SMA)." Pesat, 2, B1-B4. Available http://ejournal.gunadarma.ac.id, diakses 14 Desember 2015. 